\section{Effects of Growing Substrate, Mode of Nutrient Supply, and Saffron Corm Size on Flowering, Growth, Photosynthetic Competence, and Cormlet Formation in Hydroponics}

\author{
Yaser Hassan Dewir ${ }^{1,2}$, Abdullah Alsadon ${ }^{1}$, Abdullah Ibrahim ${ }^{1}$, \\ and Mohammed El-Mahrouk ${ }^{2}$
}

ADDITIONAL INDEX wORDs. controlled environment, Crocus sativus, indoor culture, soilless culture

SUMMARY. Hydroponics is a promising method for cultivation of saffron (Crocus sativus). In this study, saffron corms were sprouted using a gradual decrease in air temperature, and they were cultivated hydroponically in either perlite or volcanic rock for 24 weeks. A nutrient solution was supplied using either an ebband-flow system or continuous immersion. First blooming was observed 29 days after transplantation. Among flowering traits, only the stigma length was significantly influenced by the type of hydroponic system. Saffron plants displayed better growth parameters, a higher photosynthetic rate and stomatal conductance $\left(g_{\mathrm{s}}\right)$, as well as daughter corm (cormlet) production under the continuous immersion system, in comparison with the ebb-and-flow system. Small corms (22-25 mm diameter) did not bloom, and the emergence of flowers increased with corm size. Plant growth and photosynthetic parameters, as well as cormlet production, significantly increased with corm size. We obtained the highest stigma yield [number of flowers (1.9), stigma length $(39.4 \mathrm{~mm})$, stigma fresh $(42.8 \mathrm{mg})$, and dry weight $(5.3 \mathrm{mg})$ ] and cormlet yield [number of cormlets $(5.7)$, average corm diameter $(25 \mathrm{~mm})$, and fresh weight $(6.4 \mathrm{~g})]$ using mother corms sized $\geq 32 \mathrm{~mm}$ diameter grown hydroponically in the volcanic rock-based continuous immersion system.

$S$ affron (Crocus satious) is a geophyte perennial plant from the family Iridaceae with underground soft corms. It is a valuable crop that has been cultivated as a spice for at least 3,500 years. The name "saffron" comes originally from the Arabic word za-faran, meaning "yellow" (Winterhalter and Straubinger, 2000). The stigmas constitute the commercial

Received for publication 25 Oct. 2021. Accepted for publication 28 Jan. 2022.

Published online 25 February 2022

${ }^{1}$ Plant Production Department, P.O. Box 2460, College of Food and Agricultural Sciences, King Saud University, 11451 Rivadh, Saudi Arabia

${ }^{2}$ Department of Horticulture, Faculty of Agriculture, Kafrelsheikh University, Kafr El-Sheikh 33516, Egypt

This Project was funded by the National Plan for Science, Technology and Innovation (MAARIFAH), King Abdulaziz City for Science and Technology, Kingdom of Saudi Arabia, Award Number (15 AGR3704-02)

Y.H.D. is the corresponding author E-mail: ydewir@ksu.edu.sa.

This is an open access article distributed under the CC BY-NC-ND license (https://creativecommons. org/licenses/by-nc-nd/4.0/).

https://doi.org/10.21273/HORTTECH04980-21 product saffron that has coloring, flavoring, and therapeutic properties (Abdullaev and Frenkel, 1999). It is a highly priced spice because of its high demand and low supply. The labor needed for saffron production is reflected in its high cost (Douglas et al., 2014; Gresta et al., 2017; cesses, such as planting, flower harvesting, and separation of the stigmas, are labor-intensive and time-consuming. Each saffron flower has three stigmas, and produces nearly $5 \mathrm{mg}$ dry weight. Between 150,000 and 200,000 saffron flowers and more than $400 \mathrm{~h}$ of labor Molina et al., 2004). Cultivation pro- are required to yield $1 \mathrm{~kg}$ of saffron stigmas (Mzabri et al., 2019).

Saffron is a sterile autotriploid and stemless monocotyledonous autumnflowering geophyte plant (Ali et al., 2018; Nemati et al., 2019). Its corm survives for only one season, and it reproduces new cormlets formed above the old one during each season, which gives rise to new plants. Therefore, daughter corms produced by mother corms are the only propagation method of saffron (Douglas et al., 2014). A mother saffron corm produces typically one to four cormlets per season through field cultivation (Ali et al., 2018; Cavusoglu and Erkel, 2005). Difficulties in its cultivation in limited farmland located at high altitudes under cold climate conditions and laborious nature of harvesting and handling (Douglas et al., 2014; Khilare et al., 2019; Kumar et al., 2008) have made saffron the most expensive spice in the world (Aytekin and Acikgoz, 2008; Winterhalter and Straubinger, 2000). The low rate of cormlet multiplication and associated fungal infections hinder saffron pr oductivity (Devi et al., 2011). In addition, low saffron yield is partly the result of application of conventional agronomic practices (Koul, 1999).

Cultivation systems based on controlled conditions can be a suitable replacement for conventional saffron cropping (Mollafilabi et al., 2013); however, the production of pathogenfree corms is required to modernize saffron cultivation (Plessner and Ziv, 1999). Thus, saffron cultivation performed under controlled conditions in plastic tunnels and hydroponic beds can be a convenient approach because plant growth and application of nutrition medium are both controlled, and it is possible to achieve a higher yield and a better quality. However, few studies that include new growing techniques have been conducted, such as forcing saffron to bloom under

\begin{tabular}{llll}
\hline $\begin{array}{l}\text { Units } \\
\text { To convert U.S. to SI, } \\
\text { multiply by }\end{array}$ & U.S. unit & SI unit & $\begin{array}{l}\text { To convert SI to U.S., } \\
\text { multiply by }\end{array}$ \\
\hline 2.54 & inch(es) & $\mathrm{cm}$ & 0.3937 \\
25.4 & inch(es) & $\mathrm{mm}$ & 0.0394 \\
6.4516 & inch & $\mathrm{cm}^{2}$ & 0.1550 \\
0.4536 & $\mathrm{lb}$ & $\mathrm{kg}$ & 2.2046 \\
1 & $\mathrm{mmho} / \mathrm{cm}$ & $\mathrm{dS} \cdot \mathrm{m}^{-1}$ & 1 \\
28.3495 & $\mathrm{oz}$ & $\mathrm{g}$ & 0.0353 \\
28,350 & $\mathrm{Oz}$ & $\mathrm{mg}$ & $3.5274 \times 10^{-5}$ \\
1 & $\mathrm{ppm}$ & $\mathrm{mg} \cdot \mathrm{L}^{-1}$ & 1 \\
$\left({ }^{\circ} \mathrm{F}-32\right) \div 1.8$ & ${ }^{\circ} \mathrm{F}$ & ${ }^{\circ} \mathrm{C}$ & $\left({ }^{\circ} \mathrm{C} \times 1.8\right)+32$
\end{tabular}


decreased temperatures and in specialized incubation chambers (GarcíaRodríguez et al., 2017; Molina et al., $2004,2005 a)$, as well as in greenhouses (Poggi et al., 2010) or under hydroponic conditions (Souret and Weathers, 2000), to increase overall production and produce saffron out of its natural season. Souret and Weathers (2000) suggested that both aeroponics and hydroponics could be used for growing saffron corms as a practical and renewable source of pharmacological compounds. Helalbeigi et al. (2009) reported that it was possible to cultivate saffron corms in various beds in a soilless cultivation system. These authors also claimed that cultivation in cocopeat and perlite beds increased the dry weight of saffron corms. Recently, Schroeder et al. (2020) reported a shorter growth period and increased yield of saffron using the hydroponic "spikes-tray-system" coupled with a peat substrate greenhouse cultivation, where the corms were produced in an open field and later transferred to a growth chamber for flowering.

Hydroponics represent a valuable alternative to open-field saffron production (Maggio et al., 2006). It can increase the yield of saffron, while reducing its production costs (Molina et al., 2005b). Furthermore, it has tremendous potential for sustainable production of saffron by providing pathogen-free stock corms. However, to produce saffron efficiently, a hydroponic system and growth conditions should be optimized. This study thus investigated the effects of the growing substrate, mode of nutrient supply, and corm size on flowering, growth, photosynthesis, and cormlet production of saffron in a hydroponic system under a controlled environment.

\section{Materials and methods}

Plant material. Saffron corms were obtained from Bloembollenbedriif J.C.Koot (Vennewatersweg, The Netherlands). We peeled the corms (Fig. 1A) and discarded those injured or infected. Next, we dipped the corms in a fungicide solution that contained $75 \mathrm{mg} \cdot \mathrm{L}^{-1}$ metalaxyl and $175 \mathrm{mg} \cdot \mathrm{L}^{-1}$ copper oxychloride (Aromil-Plus 50 WP; Mobedco-Vet, Amman, Jordan) to prevent fungal infestation and dried them before planting. We planted corms into plastic pots $(6 \mathrm{~cm}$ diameter) filled with a mixture of perlite and

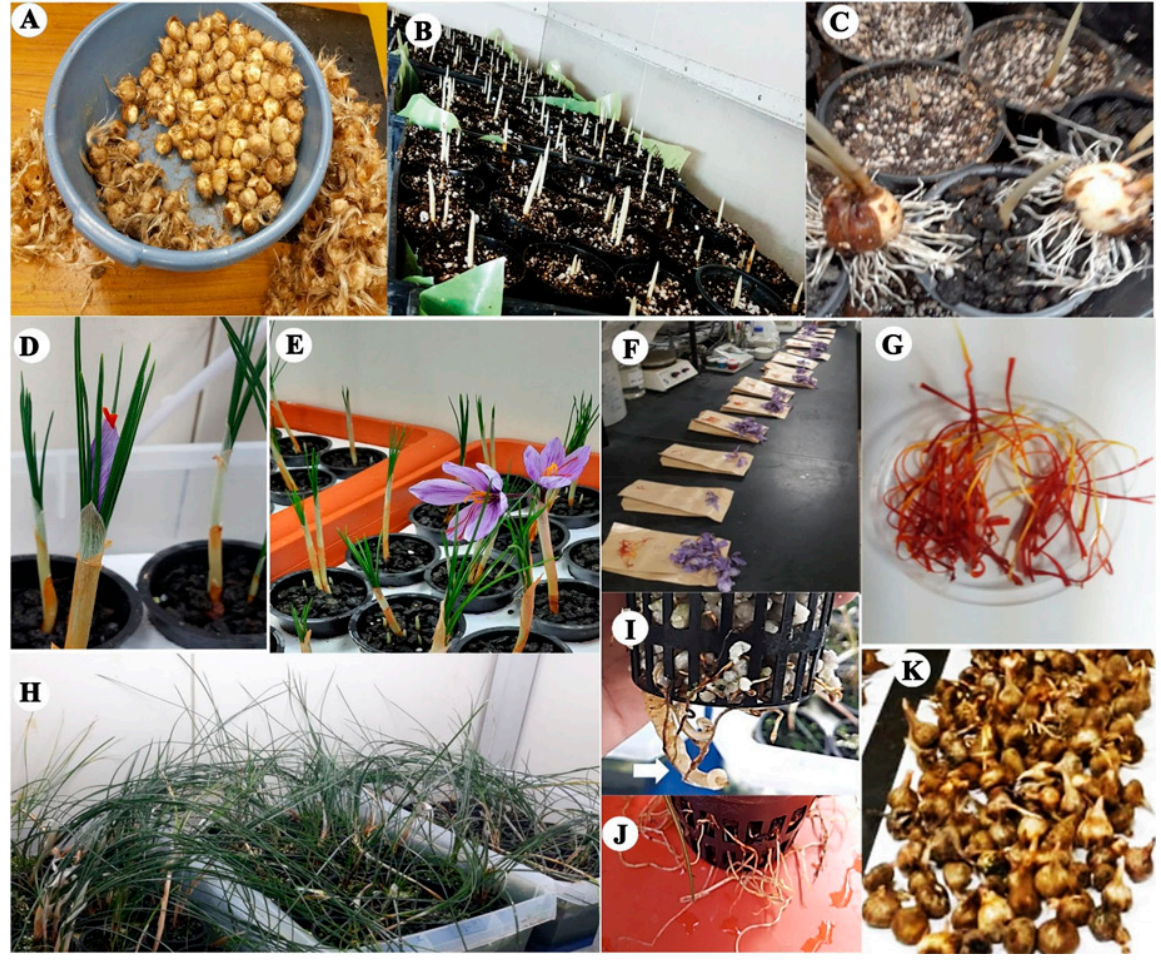

Fig. 1. Flowering, growth and cormlets production of saffron [size $4(3.2-3.5 \mathrm{~cm}$ diameter)] in the hydroponic culture system: (A) corm peeling and disinfection, $(B, C)$ sprouted corms and root emergence after 2 weeks of incubation at $14^{\circ} \mathrm{C}$ for 1 week followed by $12{ }^{\circ} \mathrm{C}$ for a subsequent week in controlled growth chamber and dark conditions, $(D, E)$ first flower emergence in the hydroponic system incubated at $8 \pm 1{ }^{\circ} \mathrm{C}$ air temperature after $29 \mathrm{~d}$ of corm transplanting, $(F, G)$ harvesting of flowers and stigmas, $(\mathrm{H})$ plant growth after 20 weeks of transplanting in the hydroponics at $8 \pm 1{ }^{\circ} \mathrm{C}$ air temperature and $80 \mu \mathrm{mol} \cdot \mathrm{m}^{-2} \cdot \mathrm{s}^{-1}$ photosynthetic photon flux density, (I) contractile roots of saffron plants grown in perlite based ebb-and-flow system, $(\mathrm{J})$ fibrous roots of saffron grown in volcanic rock-based aerated continuous immersion system, and $(\mathrm{K})$ cormlets produced after 24 weeks of growth in the hydroponics system; $\left(1.8 \times{ }^{\circ} \mathrm{C}\right)+$ $32={ }^{\circ} \mathrm{F}, 1 \mathrm{~cm}=0.3937$ inch.

peatmoss $(1: 1 ; \mathrm{v} / \mathrm{v})$ to initiate sprouting. The pots were irrigated and incubated at $14^{\circ} \mathrm{C}$ in the dark in a controlled temperature-growth chamber for 1 week followed by incubation at $12{ }^{\circ} \mathrm{C}$ for another week.

GrowING SUBSTRATES AND MODE OF NUTRIENT SUPPLY IN HYDROPONICS. We transplanted sprouted corms $[3-5$ $\mathrm{cm}$ length (Fig. 1A-C)] of the size 4 $(10-11 \mathrm{~cm}$ circumference, $3.2-3.5 \mathrm{~cm}$ diameter) into hydroponic plastic pots $(10 \mathrm{~cm} \times 8 \mathrm{~cm})$ filled with either volcanic rock or perlite, and placed the pots onto floating polyurethane foam board $(60 \mathrm{~cm} \times 40 \mathrm{~cm} \times 3 \mathrm{~cm})$ purchased from a local supermarket. Each board had 20 pots and was placed in a tank to supply the plants with a nutrient solution (Nabtah, HydroArabia; Hasad AlDahab Factory for Liquid Fertilizers, Riyadh, Saudi Arabia). We adjusted the electrical conductivity (EC) of the nutrient solution to $1.4 \mathrm{dS} \cdot \mathrm{m}^{-1}$ using a multiparameter bench meter (MI 180-US; Milwaukee Instruments, Rocky Mount, NC) and maintained it by providing a fresh solution with the $\mathrm{pH}$ value adjusted to $5.8 \pm 0.2$. The nutrient solution contained $\left(\mathrm{mg} \cdot \mathrm{L}^{-1}\right)$ 163.20 nitrogen $(\mathrm{N}), 34.53$ phosphorus $(\mathrm{P}), 172.56$ potassium $(\mathrm{K}), 105.11$ calcium $(\mathrm{Ca}), 33.83$ magnesium $(\mathrm{Mg})$, and 62.70 sulfur $(S)$ as macronutrients. Micronutrients of the solution were composed of $\left(\mathrm{mg} \cdot \mathrm{L}^{-1}\right) 1.83$ iron $(\mathrm{Fe})$, 0.23 boron $(\mathrm{B}), 0.27$ manganese $(\mathrm{Mn}), 0.19$ zinc $(\mathrm{Zn}), 0.12$ copper $(\mathrm{Cu})$, and 0.07 molybdenum (Mo). Saffron corms were grown in either the ebb-and-flow system or the continuous immersion system. A layout of the hydroponic systems used in this study is presented in Fig. 2. We programmed the ebb-and-flow system to immerse the plants in the nutrient solution for 


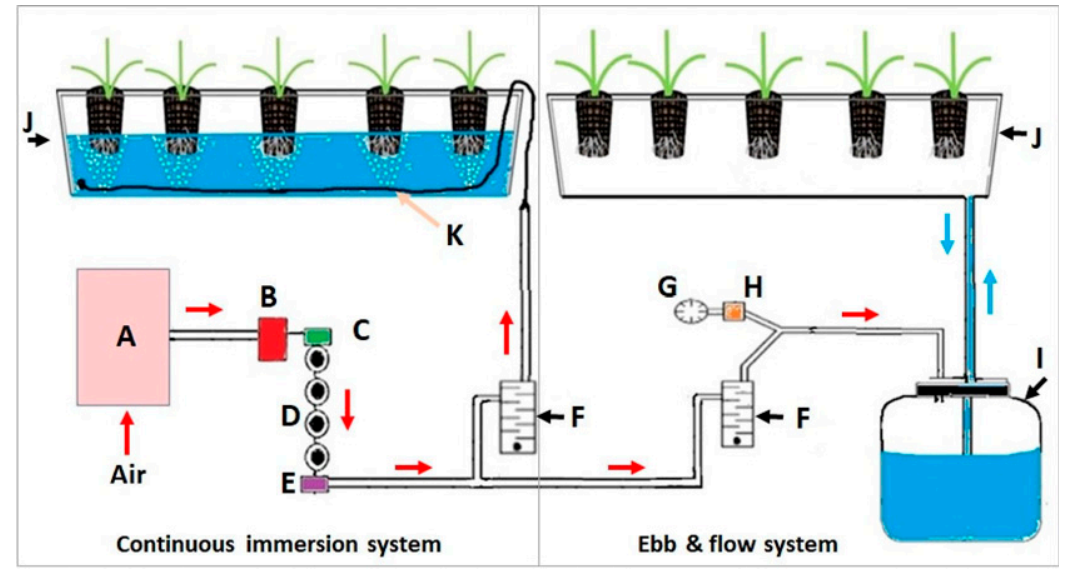

Fig. 2. Schematic diagram of continuous immersion and ebb-and-flow hydroponic systems used for growing saffron: (A) air compressor, (B) air reservoir, (C) air cooling, (D) air filter system, (E) air dryer, (F) air flow meter, (G) timer, (H) solenoid valve, (I) nutrient solution tank, (J) growing vessels, (K) airline tube.

6 or $12 \mathrm{~h}$ (six times per day with varied immersion durations of either 1 or $2 \mathrm{~h}$ in each cycle). For the continuous immersion system, air of $0.3 \mathrm{v} / \mathrm{v} / \mathrm{min}$ (air volume/nutrient solution volume/minute) was supplied into the nutrient solution. The plantlets were continuously submerged in the solution to maintain a constant nutrient and water status in the root zone. We exposed sprouted corms to a gradual air temperature decrease for 2 weeks, starting from $10^{\circ} \mathrm{C}$ and finishing with $8^{\circ} \mathrm{C}\left(2^{\circ} \mathrm{C}\right.$ per week $)$ and subsequently cultivated them at $8 \pm 1{ }^{\circ} \mathrm{C}$ until harvesting daughter corms at the leaf senescence stage. Light intensity was adjusted to $100 \mu \mathrm{mol} \cdot \mathrm{m}^{-2} \cdot \mathrm{s}^{-1}$ photosynthetic photon flux density for a 16/8 h light/dark cycle provided by cool white fluorescent lamps.

GROWTH CONDITIONS OF CORMS OF DIFFERENT SIZES IN HYDROPONICS. We graded saffron corms (Fig. 3) into four groups as follows: size $1(7-8 \mathrm{~cm}$ circumference, $2.2-2.5 \mathrm{~cm}$ diameter), size 2 (8-9 cm circumference, 2.5-2.8 $\mathrm{cm}$ diameter), size $3(9-10 \mathrm{~cm}$ circumference, $2.8-3.2 \mathrm{~cm}$ diameter), and size 4 (10-11 cm circumference, $3.2-3.5 \mathrm{~cm}$ diameter). We cultivated all of the corms in a volcanic rock substrate in the continuous immersion system with an air supply of $0.3 \mathrm{v} / \mathrm{v} / \mathrm{min}$ to evaluate their flowering, growth performance, and cormlet production parameters. All culture conditions were set as described previously.

FLOWERING, VEgETATIVE GROWTH, AND CORMLET FORMATION PARAMETERS. We recorded flowering parameters (number of flowers per plant, and cormlet fresh weight) was recorded 24 weeks after corm sprouting.

Photosynthetic parameters. We recorded photosynthetic rate, and gs using a portable photosynthesis system (LI-6400; LI-COR Biosciences, Lincoln, NE) equipped with a standard $2 \mathrm{~cm} \times 3 \mathrm{~cm}$ leaf cuvette and a light source (LI-6400-02B; LI-COR Biosciences). We measured the parameters under the carbon dioxide $\left(\mathrm{CO}_{2}\right)$ concentration in the inflow air of 350 $\mu \mathrm{mol} \cdot \mathrm{mol}^{-1}$ under the relative humidity values of $60 \%$ and leaf temperature of $8^{\circ} \mathrm{C}$ at ambient conditions. We performed the measurements on the young leaf of three randomly selected plants from each treatment.

EXPERIMENTAL DESIGN AND DATA ANALYSIS. The experiment on growing substrates and mode of nutrient supply was set up using a completely randomized factorial design, whereas the experiment on different corm sizes was set up using a completely randomized design. The factorial design has two substrates (volcanic rock and perlite) and two modes of nutrient supply (ebb-and-flow system and aerated continuous immersion system). Each treatment had three replicates and each replicate was represented by a floating tray that contained 20 pots; each pot contained one plant. We assessed the effects of the treatments using analysis of variance and Tukey's multiple range test (SAS ver. 6.12; SAS Institute, Cary, NC).

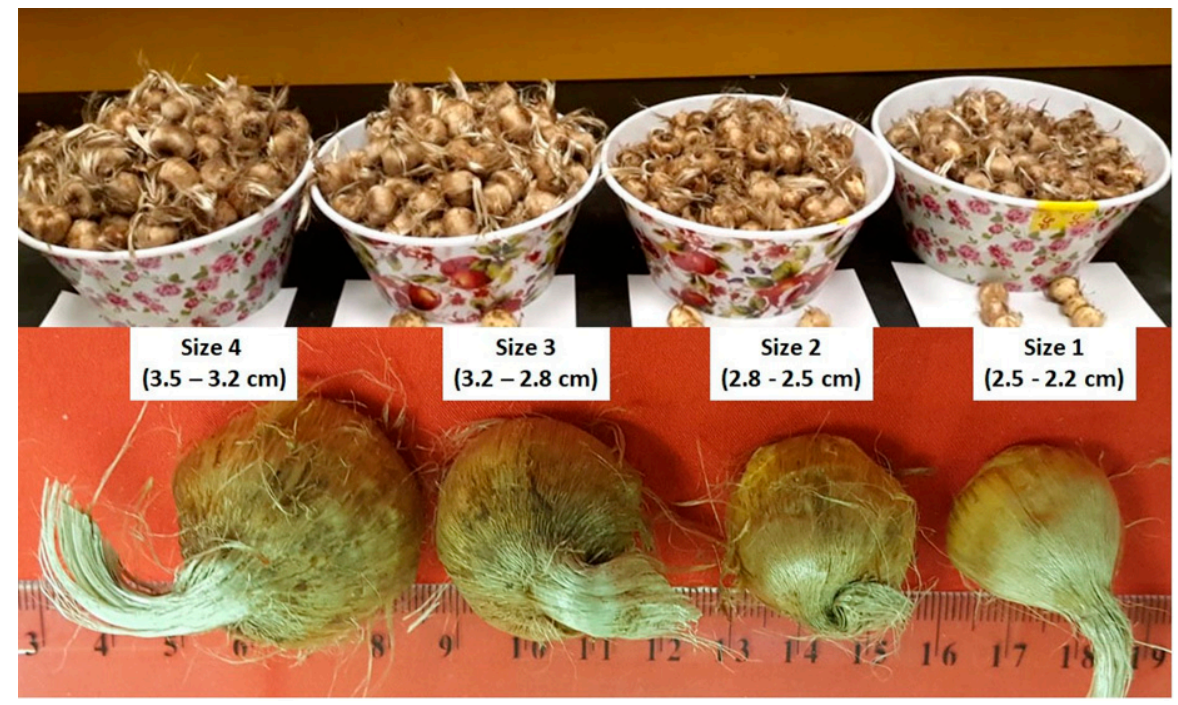

Fig. 3. Different corm sizes of saffron transplanted in the continuous immersion hydroponic system using volcanic rock substrate and a 0.3 air volume/nutrient solution volume $/$ minute air supply; $1 \mathrm{~cm}=0.3937$ inch . 


\section{Results and discussion}

EFFECTS OF GROWING SUBSTRATES AND THE MODE OF NUTRIENT SUPPLY. Both the growing substrate type and the mode of nutrient supply to the roots of saffron plants, either by the continuous immersion or the ebband-flow system, significantly influenced vegetative growth, photosynthetic capacity, and cormlet production (Table 1). Saffron plants grown in the volcanic rock-based continuous immersion system displayed the highest plant height, leaf fresh and dry weight, and leaf area compared with other treatments. The continuous immersion system was better for saffron growth than the ebb-and-flow system. In the ebband-flow system, immersion of saffron roots for $6 \mathrm{~h}$ showed better results than the 12 -h treatment that rendered the lowest growth parameters and cormlet production values. The highest number of cormlets (5.8), average cormlet diameter $(24.1 \mathrm{~mm})$, and weight $(6.62$ g) were recorded from the volcanic rock-based continuous immersion system. Conversely, we did not find a dependence of saffron flowering parameters on the type of hydroponic system, growing substrate type, or their interaction, except for the stigma length that was significantly influenced by the hydroponic system type (Table 1). Stigma length was the highest $(41.8 \mathrm{~mm})$ in the continuous immersion system.

It has been reported that temperature, among several environmental parameters, plays a pivotal role in saffron flower induction (Kafi et al., 2002; Molina et al., 2005a, 2005b). Therefore, saffron corms were incubated at a moderately high temperature $\left(23\right.$ to $\left.27^{\circ} \mathrm{C}\right)$ to induce flowering, followed by the exposure to a moderately low temperature $\left(17^{\circ} \mathrm{C}\right)$ for floral emergence. Under field conditions, floral initiation usually occurs during summer, coinciding with the revival of meristematic activity in the apical bud. Thus, corms can be directly cultivated in the field to force flowering or can be stored up to $60 \mathrm{~d}$ at $2{ }^{\circ} \mathrm{C}$ to extend and facilitate harvesting (Amooaghaie, 2007; Mollafilabi et al., 2017). Amooaghaie (2007) reported that storing saffron corms at a freezing temperature damaged them, and prolonged cold storage delayed flowering and greatly reduced stigma yield. In the present study, saffron corms were exposed to a

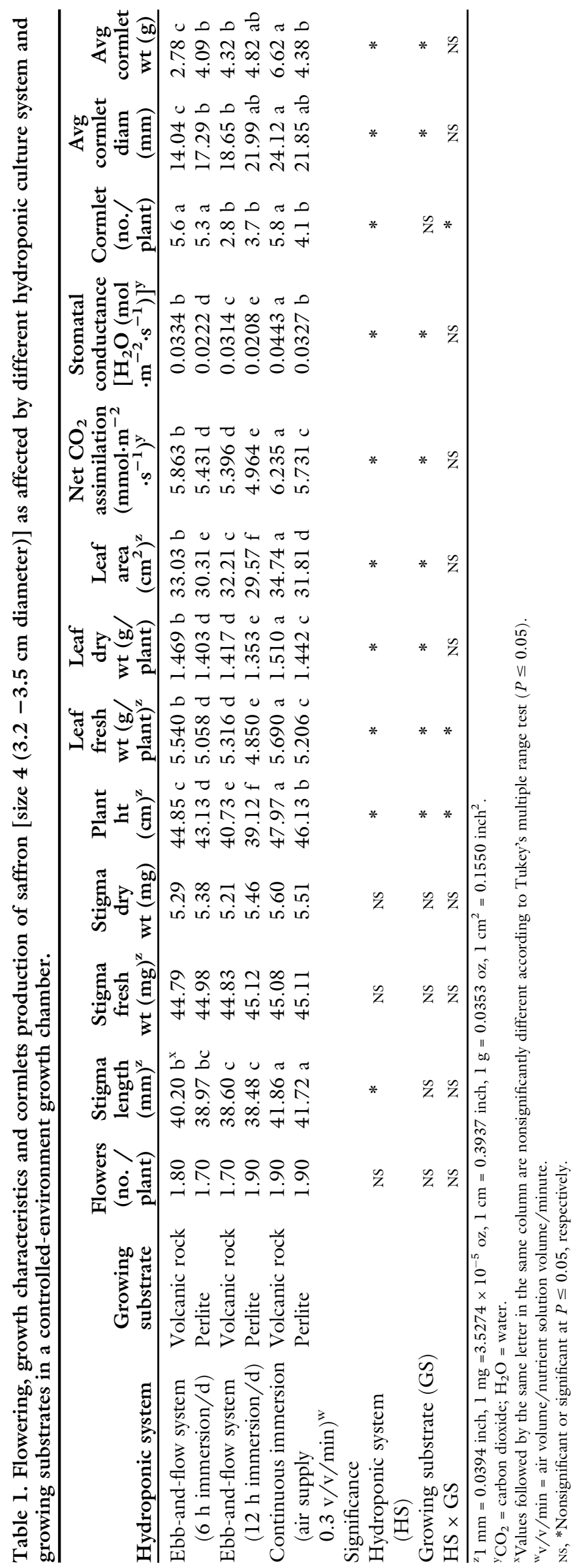


gradual air temperature decrease for 4 weeks, starting at $14^{\circ} \mathrm{C}$ and finishing at $8^{\circ} \mathrm{C}\left(2^{\circ} \mathrm{C}\right.$ per week $)$. First emergence of flowers was observed $29 \mathrm{~d}$ after corm transplantation (Fig. ID and E), and harvesting of flowers (Fig. IF and G) lasted for $20 \mathrm{~d}$. Earlier flowering in a growth chamber compared with glasshouse-grown plants (days 93 vs. 103 after transplanting), was reported by Maggio et al. (2006).

Selection of suitable substrates and setting the optimal environmental control can significantly affect plant growth (Dewir et al., 2004, 2005a, 2005b; Saleh et al., 2019). We found that the type of growing substrates (perlite and volcanic rock) had no significant effect on flowering traits, but significantly influenced plant growth, photosynthetic rate, $\mathscr{g}_{\mathrm{S}}$, and cormlet formation (Table 1, Fig. 1H). Maggio et al. (2006) reported similar observations for corms forced in a cold glasshouse, in which perlite and vermiculite substrates did not affect flowering yield, but only a larger leaf area per plant was obtained in vermiculite in comparison with perlite.

In the present study, root formation of saffron plants was affected by the mode of nutrient supply and growing substrate type. Contractile roots, short, and thick fibrous roots were observed in a perlite substrate (Fig. 1I), whereas thinner and longer ones were observed in volcanic rock (Fig. 1J). The aerated continuous immersion system favored growth of fibrous roots compared with the ebb-and-flow system. A previous study by Souret and Weathers (2000) indicated that saffron roots were shorter, thicker, and contractile and that their growth was significantly reduced in a soilless culture compared with culturing in soil. Previous studies offered explanations of this phenomenon, including mechanical resistance that impedes root growth (Zobel, 1991), presence of light conditions that suppress root growth (Poovaiah and Reddy, 1991; Souret and Weathers, 2000), or oxygen deficiency that leads to hypoxia and alters root growth. However, intensive root growth of saffron plants observed in the applied continuous immersion system might be promoted by continuous aeration providing sufficient oxygen to the roots, accounting for vigorous plant growth and increased cormlet formation compared with the ebb-and-flow system.
EFFECT OF CORM SIZE ON GROWTH, PHOTOSYNTHETIC, AND YIELD PARAMETERs. Table 2 presents the effect of corm size on flowering, growth, and cormlet production of saffron grown in the aerated continuous immersion hydroponic system. Corms that were small [size l (2.2-2.5 cm diameter)] did not flower. Flowering parameters (number of flowers, stigma length, stigma fresh and dry weight) increased with increased corm size. Similarly, vegetative growth and photosynthetic parameters, as well as cormlet production, were affected by corm size. Corm size $4(3.2-3.5 \mathrm{~cm})$ recorded the highest values of flowering and vegetative growth parameters, as well as of cormlet production (Table 2). Saffron has a globular corm with diameters ranging from 0.5 to 5.0 $\mathrm{cm}$, and its weight ranges from 1 to $20 \mathrm{~g}$, depending on environmental conditions and agricultural management (Ali et al., 2018; Douglas et al., 2014 ). Each corm can produce one to four apical shoots containing developing flower and leaf (Ali et al., 2018). Mother corm size and weight have a significant impact on flowering and the number of daughter corms produced (Ali et al., 2018; Bayat et al., 2016; Douglas et al., 2014). Small mother corms $(<1 \mathrm{~cm}$ diameter and $<6 \mathrm{~g}$ fresh weight) do not flower and produce nonflowering cormlets (Ali et al., 2018; Douglas et al., 2014). Previous reports indicate that large corms $(\geq 10 \mathrm{~g})$ produce a high yield of stigma and numerous cormlets because they serve as a reservoir of nutrients and have a greater ability to take up water and nutrients than small corms (Ali et al., 2018; Douglas et al., 2014; Ghobadi et al., 2015; Koocheki et al., 2016a, 2016b; Mollafilabi et al., 2013). By decreasing corm weight, stigma yield and daughter corm production drop significantly (Askari-Khorasgani and Pessarakli, 2019; Koocheki et al., 2016a). From the commercial point of view, a corm that is 2.5 to $3.5 \mathrm{~cm}$ in diameter (8-16 g and mostly 8-11 g) appears to be the most common corm size used for planting (Douglas et al., 2014; Koocheki et al., 2016a). In a hydroponic system, corm size plays a critical role in saffron flowering. It was observed that only corms $>2.6 \mathrm{~cm}$ diameter bloomed (Souret and Weathers, 2000). In addition, small corms

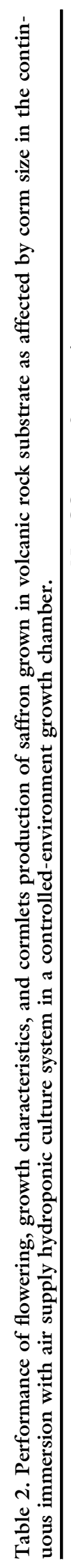

\section{光} 赵离

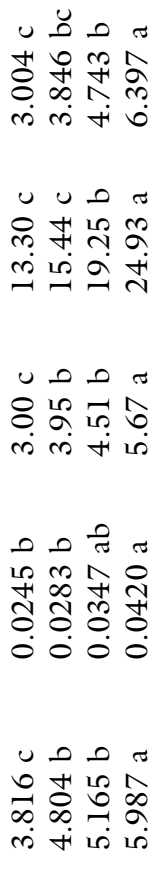
'

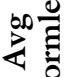
常 .

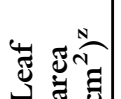

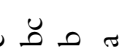
ฮี ฮี ฮี อิ ते (⿻) 
$(<2.6 \mathrm{~cm})$ presented poor flowering in aeroponics, hydroponics, and soil (Souret and Weathers, 2000). Cavusoglu and Erkel (2005) studied the effect of size of greenhouse-cultivated saffron corms and found that the number of flowers and time of flowering were both dependent on the size of mother corms. Corm size plays a central role in the life cycle of saffron because a corm provides storage for photosynthetic products that are most needed after dormancy and at early stages of crop growth (Alvarez-Orti et al., 2004). Corm size has also been shown to affect the production of saffron flowers (De-Maastro and Ruta, 1993) and differences in the period required for flower initiation have been attributed mostly to the corm size (Negbi, 1999). In larger corms, cell division and, consequently, leaf growth occur somewhat earlier than in smaller ones. Therefore, saffron plants obtained from larger corms produce more leaf area compared with those from smaller corms (De-Maastro and Ruta, 1993). Earlier growth and larger leaf positively affect the photosynthetate accumulation, finally resulting in larger daughter corms at the end of the growing season (Molina et al., 2005b).

\section{Conclusions}

Saffron plants flowered in hydroponics $29 \mathrm{~d}$ following transplantation under a gradual air temperature decrease. Flowering was not influenced either by the growing substrate or the mode of nutrient supply; however, it was significantly influenced by corm size. Optimized yields of saffron stigma and daughter corms can be achieved in a controlled environment using largesized corms transplanted to volcanic rock-based aerated continuous immersion hydroponics. Further investigation regarding the optimization of growth conditions is required to obtain an increase in daughter corm size.

\section{Literature cited}

Abdullaev, F.I. and G.D. Frenkel. 1999. Saffron in biological and medical research, p. 103-111. In: M. Negbi (ed.). Saffron. Crocus sativus L. Harwood Academic Publishers, Amsterdam, Netherlands.

Ali, G., F.A. Nehvi, A. Arshid, S. Naseer, S.A. Nagoo, N.A. Dar, and A.M. Iqbal. 2018. Effect of colchicine and corm weight on daughter corm formation in saffron (Crocus sativus L.). Acta Hort.
1200:153-158, https://doi.org/10.17660/ ActaHortic.2018.1200.25.

Alvarez-Orti, M., L. Gomez-Gomez, A. Rubio, J. Escribano, J. Pardo, F. Jimenez, and J.A. Fernandez. 2004. Development and gene expression in saffron corms. Acta Hort. 650:141-148, https://doi. org/10.17660/ActaHortic.2004.650.14.

Amooaghaie, R. 2007. Low temperature storage of corms extends the flowering season of saffron (Crocus sativus L.). Acta Hort. 739:41-47, https://doi.org/10.17 660/ActaHortic.2007.739.3.

Askari-Khorasgani, O. and M. Pessarakli. 2019. Shifting saffron (Crocus sativus L.) culture from traditional farmland to controlled environment (greenhouse) condition to avoid the negative impact of climate changes and increase its productivity. J. Plant Nutr. 42:2642-2665, https://doi. org/10.1080/01904167.2019.1659348.

Aytekin, A. and O.A. Acikgoz. 2008. Hormone and microorganism treatments in the cultivation of saffron (Crocus sativus L.) plants. Molecules 13:1135-1147, https:// doi.org/10.3390/molecules13051135.

Bayat, M., M. Rahimi, and M. Ramezani. 2016. Determining the most effective traits to improve saffron (Crocus sativus L.) yield. Physiol. Mol. Biol. Plants 22:153-161, https://doi.org/10.1007/s12298-0160347-1.

Cavusoglu, A. and I.A. Erkel. 2005. Kocaeli Ili Kosullannda saffron (Crocus sativus L.). Akdeniz-niversitesi Ziraat Fakultesi Dergisi 18:179-184.

De-Maastro, G. and C. Ruta. 1993. Relation between corm size and saffron (Crocus sativus L.) flowering. Acta Hort. 344: 512-517, https://doi.org/10.17660/Acta Hortic.1993.344.58.

Devi, K., M. Sharma, M. Singh, and P.S. Ahuja. 2011. In vitro cormlet production and growth evaluation under greenhouse condition in saffron (Crocus sativus L.) - A commercially important crop. Eng. Life Sci. 11:189-194, https://doi.org/10.1002/ elsc. 201000080.

Dewir, Y.H., D. Chakrabarty, M.B. Ali, E.J. Hahn, and K.Y. Paek. 2005a. Effects of hydroponic solution EC, substrates, PPF and nutrient scheduling on growth and photosynthetic competence during acclimatization of micropropagated Spathiphyllum plantlets. Plant Growth Regulat. 46:241251, https://doi.org/10.1007/s10725005-0161-1.

Dewir, Y.H., E.J. Hahn, H.C. Jeong, S.D. Hong, and K.Y. Paek. 2005b. Rooting and growth of micropropagated Spathiphyllum shoots in various mixtures of growing media. Hort. Environ. Biotechnol. 46:269-274.
Dewir, Y.H., E.J. Hahn, and K.Y. Paek. 2004. Factors affecting ex vitro rooting and growth of Spathiphyllum plantlets in the microponic culture system. Weonye Gwahag Gisulji 22:42 (abstr.).

Douglas, M.H., B.M. Smallfield, A.R. Wallace, and J.A. McGimpsey. 2014. Saffron (Crocus sativus L.): The effect of mother corm size on progeny multiplication, flower and stigma production. Scientia Hort. 166:50-58, https://doi.org/ 10.1016/j.scienta.2013.12.007.

García-Rodríguez, M.V., H. LópezCórcoles, and G.L. Alonso. 2017. Effect of the hydroponic growing of forced Crocus sativus L. on the saffron quality. Acta Hort. 1184:287-292, https://doi.org/ 10.17660/ActaHortic.2017.1184.41.

Ghobadi, F., M. Javid, and A. Sorooshzadeh. 2015. Effects of planting date and corm size on flower yield and physiological traits of saffron (Crocus satious L.) under Varamin Plain climatic conditions (in Persian with English summary). J. Saffron Agron. Technol. 2:265-276.

Gresta, F., E. Napoli, G. Ceravolo, C. Santonoceto, T. Strano, and G. Ruberto. 2017. Stigmas yield and volatile compounds of saffron (Crocus satious) in a late sowing under greenhouse with two nitrogen rates. Acta Hort. 1184:293-300, https://doi. org/10.17660/ActaHortic.2017.1184.42.

Helalbeigi, Y., A.H. Khoshgoftarmanesh, F. Shamsi, and N. Zamani. 2009. Possibility of saffron corm growth in different bed of cultivation in soillers system (in Persian with English summary). Proc. lst Cong. Hydroponics Greenhouse Production. Isfahan Univ. Technol., Isfahan, Iran.

Kafi, M., M.H. Rashed Mohassel, A. Koocheki, and M. Molafilabi. 2002. Saffron: Production and processing. Ferdowsi Univ. Mashhad Press, Mashhad, Iran.

Khilare, V., A. Tiknaik, B. Prakash, B. Ughade, G. Korhale, D. Nalage, N. Ahmed, C. Khedkar, and G. Khedkar. 2019. Multiple tests on saffron find new adulterant materials and reveal that 1 st grade saffron is rare in the market. Food Chem. 272:635-642, https://doi.org/ 10.1016/j.foodchem.2018.08.089.

Koocheki, A., A. Siahmarguee, G. Azizi, and M.J. Kondori. 2016a. The effect of high density and depth of planting on agronomic characteristic of saffron (Crocus sativus L.) and corms behavior (in Persian with English summary). J. Agroecol. 3:36-49.

Koocheki, A., E. Ebrahimian, and S.M. Seyyedi. 2016b. How irrigation rounds and mother corm size control saffron yield, quality, daughter corms behavior and phosphorus uptake. Scientia Hort. 
213:132-143, https://doi.org/10.1016/ j.scienta.2016.10.028

Koul, A.K. 1999. Saffron present status and propagation. Proc. Natl. Symp. Saffron, 25-26 Nov. 1999. Reg. Res. Lab., Jammu, India. p. 21-23.

Kumar, R., V. Singh, K. Devi, M. Sharma, M.K. Singh, and P.S. Ahuja. 2008. State of art of saffron (Crocus satious L.) agronomy: A comprehensive review. Food Rev. Int. 25:44-85, https://doi.org/10.1080/875 59120802458503 .

Maggio, A., G. Raimondi, A. Martino, and S. De Pascale. 2006. Soilless cultivation of saffron in Mediterranean environment. Acta Hort. 718:515-522, https://doi.org/ 10.17660/ActaHortic.2006.718.60.

Molina, R.V., M. Valero, Y. Navarro, A. García-Luis, and J.L. Guardiola. 2005a. Low temperature storage of corms extends the flowering season of saffron ( $\mathrm{Cro}^{-}$ cus sativus L.). J. Hortic. Sci. Biotechnol. 80:319-326, https://doi.org/10.1080/ 14620316.2005 .11511937$.

Molina, R.V., M. Valero, Y. Navarro, J.L. Guardiola, and A. García-Luis. 2005b. Temperature effects on flower formation in saffron (Crocus sativus L). Scientia Hort. 103:361-379, https://doi.org/ 10.1016/j.scienta.2004.06.005.

Molina, R.V., M. Valero, Y. Navarro, A. García-Luis, and J.L. Guardiola. 2004. The effect of time of corm lifting and duration of incubation at inductive temperature on flowering in the saffron plant (Crocus sativus L.). Scientia Hort. 103: 79-91, https://doi.org/10.1016/j.scienta. 2004.04.008.
Mollafilabi, A., A. Koocheki, P. Rezvani Moghaddam, and M. Nassiri Mahallati. 2017. Effects of bed type, corm weight and lifting time on quantitative and qualitative criteria of saffron (Crocus sativus L.). J. Agroecol. 9:607-617, https://doi. org/10.22067/jag.v9i3.26955.

Mollafilabi, A., A. Koocheki, H. Moeinerad, and L. Kooshki. 2013. Effect of plant density and weight of corm on yield and yield components of saffron (Crocus sativus L.) under soil, hydroponic and plastic tunnel cultivation. Acta Hort. 997:51-58, https://doi.org/10.17660/ActaHortic. 2013.997.5.

Mzabri, I., M. Addi, and A. Berrichi. 2019. Traditional and modern uses of saffron (Crocus satious). Cosmetics 6:63, https://doi.org/10.3390/cosmetics604 0063.

Negbi, M. 1999. Saffron cultivation: Past, present and future prospects, p. 1-17. In: M. Negbi (ed.). Saffron (Crocus sativus L.). Harwood Academic Publishers, Amsterdam, Netherlands.

Nemati, Z., D. Harpke, A. Gemicioglu, H. Kerndorff, and F.R. Blattner. 2019. Saffron (Crocus sativus) is an autotriploid that evolved in Attica (Greece) from wild Crocus cartwrightianus. Mol. Phylogenet. Evol. 136:14-20, https://doi.org/10.1101/537 688 .

Plessner, O. and M. Ziv. 1999. In vitro propagation and secondary metabolite production in Crocus sativus L., p. 137148. In: M. Negbi (ed.). Medicinal and aromatic plants-Industrial profiles. Harwood Academic Publishers, Amsterdam, Netherlands.
Poggi, L.M., A.J. Portela, M.A. Pontin, and R.V. Molina. 2010. Corm size and incubation effects on time to flowering and threads yield and quality in saffron production in Argentina. Acta Hort. 850:193-198, https://doi.org/10.17660/ActaHortic. 2010.850.32.

Poovaiah, B.W. and A.S.N. Reddy. 1991. Calcium and root development, p. 205-227. In: Y. Waisel and A. Eshel (eds.). Plant roots: The hidden half. Marcel Dekker, New York, NY.

Saleh, H.A.R., Y.I. El-Nashar, M.F. SeragEl-Din, and Y.H. Dewir. 2019. Plant growth, yield and bioactive compounds of two culinary herbs as affected by substrate type. Scientia Hort. 243:464 471, https:// doi.org/10.1016/j.scienta.2018.08.047.

Schroeder, F.-G., D.R. Lozoya, and P. Ruser. 2020. Hydroponic forcing of saffron (Crocus satious L.). Acta Hort. 1273:281288, https://doi.org/10.17660/ActaHortic. 2020.1273.37.

Souret, F.F. and P.J. Weathers. 2000. The growth of saffron (Crocus sativus L.) in aeroponics and hydroponics. J. Herbs Spices Med. Plants 7:25-35, https://doi. org/10.1300/J044v07n03_04.

Winterhalter, P. and M. Straubinger. 2000. Saffron - Renewed interest in an ancient spice. Food Rev. Int. 16:39-59, https:// doi.org/10.1081/FRI-100100281.

Zobel, R.W. 1991. Root growth and development, p. 61-71. In: D.L. Keister and P.B. Cregan (eds.). The rhizosphere and plant growth. Springer, Dordrecht, Netherlands. https://doi.org/10.1007/ 978-94-011-3336-4_7. 